\title{
Nuclear Magnetic Resonance and the BCS Theory
}

\author{
Charles P. Slichter
}

Published online: 6 November 2008

(C) Springer Science+Business Media, LLC 2008

Erratum to: J Supercond Nov Magn, Volume 21, Number 6

DOI 10.1007/s10948-008-0346-8

In the original article (first paragraph of Sect. 2), the date that John Bardeen joined the faculty of the University of Illinois is incorrect. Bardeen joined the faculty in 1951.

The online version of the original article can be found under doi:10.1007/s10948-008-0346-8.

C.P. Slichter $(\varangle)$

Department of Physics, University of Illinois, Urbana, IL 61801,

USA

e-mail: cslichte@illinois.edu 